\title{
Microbial activity in the sediment of the Sognefjord (Norway)
}

\author{
K. Poremba ${ }^{1} \&$ K. Jeskulke ${ }^{2}$ \\ ${ }^{1}$ Forschungs- und Technologiezentrum Westküste der Universität Kiel, \\ Dept. Coastal Ecology, D-25761 Büsum, Federal Republic of Germany \\ ${ }^{2}$ Institut für Meereskunde an der Universität Kiel, Abteilung Marine Mikrobiologie; \\ Düsternbrooker Weg 20, D-24105 Kiel, Germany
}

\begin{abstract}
The activity of microorganisms was investigated in sediment samples of the Norwegian Sognefjord at a $1260 \mathrm{~m}$ depth. The enzymatic potential (measured, using the cleavage of fluoresceindiacetate FDA) ranged between 11 and $29 \mathrm{nmol} \mathrm{FDA} \mathrm{cm}{ }^{-3} \mathrm{~h}^{-1}$. Labeled Anacystis sp. (Cyanobacteria) were degraded (measured as liberation of ${ }^{14} \mathrm{C}$-labeled $\mathrm{CO}_{2}$ ) at a rate of $0.67-1.24 \% \mathrm{day}^{-1}$. The assays were run at $1 \mathrm{~atm}$ and at $126 \mathrm{~atm}$ pressure. In both cases, activity was higher when samples were incubated under $1 \mathrm{~atm}$ than under simulated in-situ conditions. This indicates that the sediment community of the fjord is adapted only to a limited extent to the elevated pressure at the bottom. The results are compared and discussed with data from other deep marine environments.
\end{abstract}

\section{INTRODUCTION}

Fjords are a characteristic sign of the land-forming power of glaciers, which covered mountainous coastlines in high-latitude areas during the last ice-age 10000 years ago. On its way down to the sea, the gliding ice carved the underlying ground and left elongated, extremely deep, steep, and narrow canyons. At the seaward end the decreasing erosive strength of the glacier produced a shallow sill that often limits the exchange of water masses in and outside the fjord and creates a more or less distinct marine biotope. For example, a very shallow sill lying over the halocline may prevent the vertical water exchange, and the strong stratification can induce oxygen deficiency at the bottom making it habitable only for specially adapted organisms. This and several other aspects make fjords an interesting object of scientific studies (for a comprising overview on fjordrelated studies, see Freeland et al. [1980]).

The Norwegian Sognefjord is the world's deepest fjord, with a length of $180 \mathrm{~km}$ and a depth of up to $1300 \mathrm{~m}$. Also the smaller side-fjords leading into the main fjord possess considerable depths of several hundred meters (Fig. 1). The seaward sill of Sognefjord reaches up to $200 \mathrm{~m}$ below NN, so the water influx is hindered especially during winter and spring, and the water column is stratified. Oxygen undersaturations in the inner fjord occur frequently, but no anaerobiosis has been reported (Salen, pers. comm.).

Due to its low commercial importance, but also as a result of logistical and technical difficulties, the exploration of the Sognefjord sediment is still at a very early stage, and papers on its biology are few and far between. Here we present results of the microbial activity of the benthic system at a station located in nearly the deepest part of the Sognefjord. The potential of the enzymatic activity and the rate of respiratory degradation was studied, and it was tested, whether or not the benthic population was physiologi- 


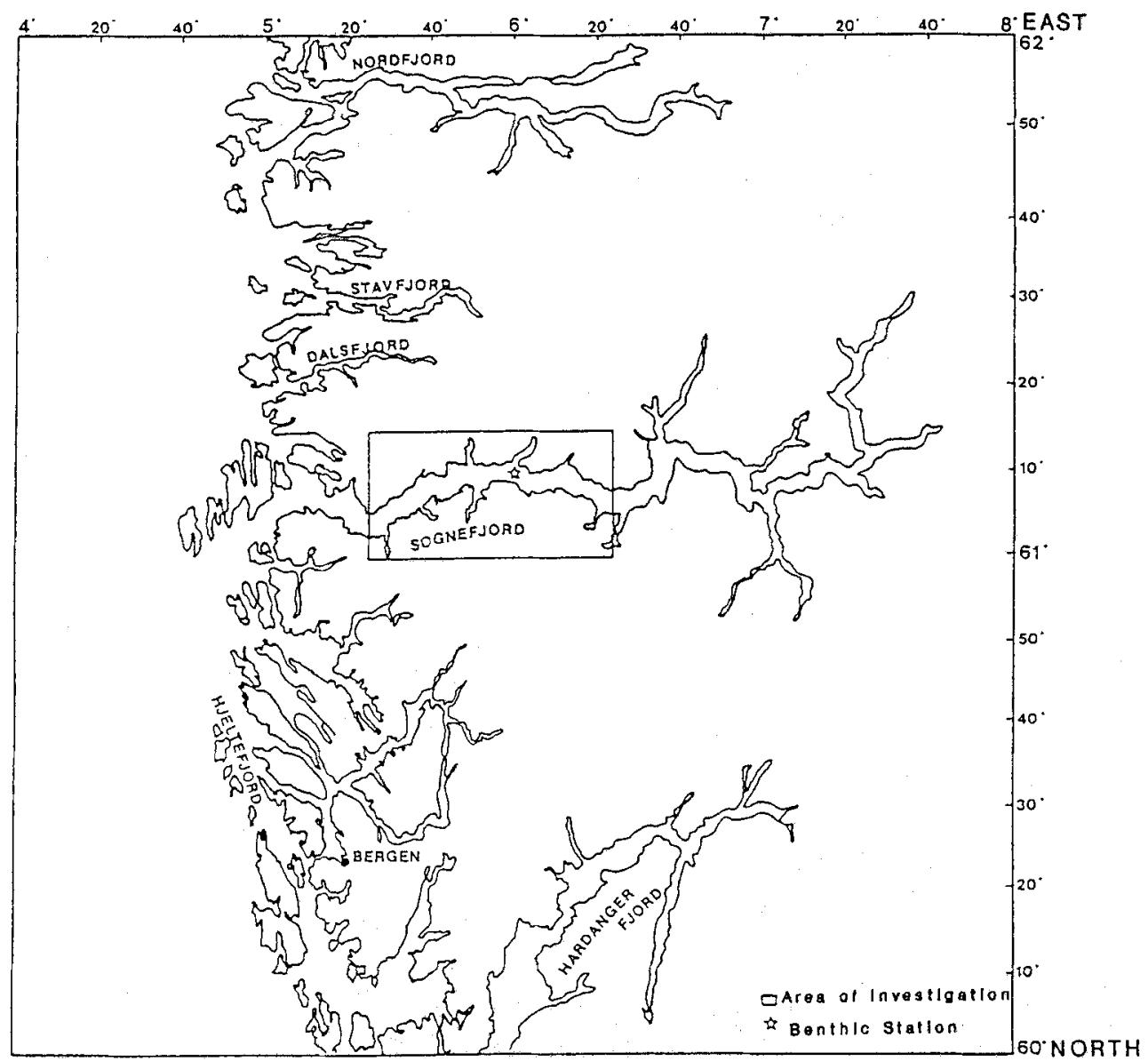

Fig. 1. Map of the area of investigation

cally adapted to the high pressure in these depths. To our knowledge, these are the first microbiological benthic data recorded for the Sognefjord.

\section{METHODS}

\section{Sampling site and shipboard handling}

Samples were collected on cruise Nr. 22 of R.V. Alkor from 22nd. Oct.-4th. Nov. 1991 at $61^{\circ} 09^{\prime} \mathrm{N} / 06^{\circ} 00^{\prime} \mathrm{E}$, which is situated near the deepest part of the Sognefjord $(1260 \mathrm{~m})$. The water column was stratified; in the surface layer $(0-50 \mathrm{~m})$ about $11{ }^{\circ} \mathrm{C}$ and $32 \% \mathrm{~S}$ were measured, and in the deep layer $(50-1260 \mathrm{~m})$ about $7^{\circ} \mathrm{C}$ and $35 \% \mathrm{~S}$.

Sediment samples were collected using a multiple corer (Barnett et al., 1984), equipped with 12 plastic tubes $(5.5 \mathrm{~cm}$ diameter, $50 \mathrm{~cm}$ length): The injection of the tubes provided a sampling of undisturbed sediment cores. On board, the cores were transferred 
immediately into a $7^{\circ} \mathrm{C}$ cooled experimental container and processed for experiments, thus minimizing the temperature shift of the probes.

\section{Preparations for activity measurements}

The enzymatic activity was followed using fluoresceindiacetate (FDA, stock solution: $9.6 \mathrm{mM}$ in acetone, Serva Chemical Co.) as substrate for hydrolytic cleavages. The $0-2$, $2-4,4-6,6-8$, and $8-10 \mathrm{~cm}$ horizons of different cores were pooled (about $300 \mathrm{ml}$ per horizon), diluted in an equal amount of deep sea water, and dispensed in aliquots of $10 \mathrm{ml}$ in sterilized polyethylene bags. FDA up to a final concentration of $96 \mu \mathrm{M}$ (saturation concentration as concluded from a previous experiment) was pipetted into the bags. Incubation followed at $7^{\circ} \mathrm{C}$ and 1 or 126 atm pressure, respectively. The high-pressure incubation was maintained in pressure vessels according to the method of Yayanos (1969). Pressurization and depressurization rates were ca $100 \mathrm{~atm} \mathrm{~min}{ }^{-1}$. The incubation was terminated after 0 (control), 2, 4, and $6 \mathrm{~h}$ taking 1 -ml sub samples ( 3 replicates) from each bag and diluting them with $6 \mathrm{ml}$ ice-cooled sea water. The sediment was centrifuged $\left(5 \mathrm{~min}, 2^{\circ} \mathrm{C}, 5000 \mathrm{rpm}\right)$ and the supernatant was read in a spectrofluorometer (Jaspo FP-550) at $470 \mathrm{~nm}$ excitation and $510 \mathrm{~nm}$ emission against an appropriate standard solution. Abiotic control series were run with sediment from individual horizons previously sterilized by autoclaving. The specific FDA-hydrolysis of each horizon was calculated by linear regression of fluorescein-release versus incubation time. Correlation coefficients were over 0.95 . In order to relate the measurements obtained from the slurry back to the undiluted sediment, dry weights of slurry and original sediment were determined. Here we present the data of hydrolysis rate per $\mathrm{h}$ and $\mathrm{cm}^{3}$ of original sediment.

The respiratoric remineralization of ${ }^{14} \mathrm{C}$-labeled Anacystis sp. (Cyanobacteria, purchased from Amersham-Buchler, $1.96 \mathrm{GBq} \mathrm{mmol}^{-1} \mathrm{C}$ ) was studied according to the method of Lochte (1992). From the $0-2 \mathrm{~cm}$ and the $4-6 \mathrm{~cm}$ horizon, respectively, $200 \mathrm{~cm}^{3}$ sediment were pooled and diluted in an equal amount of sea water. After dispensing aliquots of $10 \mathrm{~cm}^{3}$ in pre-sterilized polyethylene bags, the slurry was supplemented with $1 \mu \mathrm{Ci}\left(=18.88 \mathrm{nmol} \mathrm{C}\right.$ ) cyanobacteria and incubated $\left(7^{\circ} \mathrm{C}, 1\right.$ and $126 \mathrm{~atm}$ pressure $)$. The incubation was terminated by shock-freezing after 0 (control), 1, 2, 3, or 5 days. Two subsamples of $3 \mathrm{ml}$ were taken from each bag, supplied with $6 \mathrm{ml} 0.5 \mathrm{~N} \mathrm{NaOH}$, and centrifuged $\left(2{ }^{\circ} \mathrm{C}, 5000 \mathrm{rpm}, 10 \mathrm{~min}\right)$. From the supernatant, $7 \mathrm{ml}$ were transferred in glass bottles containing $\mathrm{CO}_{2}$-vials (a mini-vial with a paper and $250 \mu \mathrm{l}$ ethanolamine). Then, $1 \mathrm{ml} 5 \mathrm{~N} \mathrm{HCl}$ was injected into the bottles closed by a septum. The $\mathrm{CO}_{2}$ that was then bound by ethanolamine. After $24 \mathrm{~h}$ shaking, the $\mathrm{CO}_{2}$-vials were removed; $250 \mu \mathrm{l}$ ethanol and $5 \mathrm{ml}$ scintillation cocktail (Ultima Gold, Packard) was supplied, and the vials were measured on a Packard liquid scintillation counter. Recovery efficiency was $60.9 \%$. The respiration activity was calculated from the $\mathrm{CO}_{2}$-release versus incubation time. The data were based on activity per $\mathrm{h}$ and $\mathrm{cm}^{3}$ of original sediment (see FDA-method).

\section{RESULTS AND DISCUSSION}

The sediment collected in Sognefjord was fine-grained and of high water content (ranging between $600 \mathrm{mg} \mathrm{cm}^{-3}$ in the $0-1 \mathrm{~cm}^{2}$ and $350 \mathrm{mg} \mathrm{cm}^{-3}$ in the $9-10 \mathrm{~cm}$ horizon). 
The colour of the cores was bright brown in the upper $20 \mathrm{~cm}$ and dark brown in deeper horizons. No smell of $\mathrm{H}_{2} \mathrm{~S}$ was detected, which would indicate anderobiosis, so we concluded that the sediment from $0-10 \mathrm{~cm}$ - the range of our experiments - was oxygenated. Signs of terrestrial input and a rich benthic population were observed: small pieces of twigs sporadically within the sediment, burrows of unidentified infauna, macroscopic lebensspuren (traces of life), and several living megabenthic organisms (crustaceans, holothurians) were detected (Christiansen, 1994).

To assess the microbial activity in the sediment of the Sognefjord, the determination of cleavage-rate of fluoresceindiacetate (FDA) was used. FDA is a model substrate for the measurement of hydrolytic activity. The method has limitations, because an artificial substrate is used at a high, saturating concentration, thus measuring a potential activity rate and not an actual one. Nevertheless, FDA-cleavage is expected to determine the "key step in degrading organic material" (Hoppe, 1983; Meyer-Reil \& Köster, 1992). Since most of the organic material in sediments is high-molecular-weight material, needing an initial enzymatic pre-degradation, hydrolytic activity should be the ratelimiting step in organic carbon utilization (Billen, 1982; Meyer-Reil, 1990) and a prerequisite to understanding the microbial loop in aquatic ecosystems (Chrost, 1990; Hoppe, 1983).

In the sediment of the Sognefjord we found FDA degradation rates in the range of 11-29 $\mathrm{nmol} \mathrm{h}^{-1} \mathrm{~cm}^{-3}$. Since no other FDA-assays have been performed in this fjord, the present results are compared with those of other marine sediments. Lower values are reported from the deep Atlantic ocean at 4000-5000 m depth $\left(0.5-3 \mathrm{nmol} \mathrm{h}^{-1} \mathrm{~cm}^{-3}\right.$; Boetius, 1995; Köster, 1992); similar values were found in the shallow Atlantic ocean at $1200 \mathrm{~m}$ depth (Meyer-Reil \& Köster, 1992), and higher rates are reported from shallow sediments of the North Sea (Köster, 1992). This comparison might indicate that the magnitude of FDA-cleavage potential is correlated with the depth of the environment measured. However, it is more likely that the limiting factor for the potential FDA-activity is not pressure but the input of organic nutrients/carbon into the biotope. Terrestrial input should induce the synthesis of enzymes for the degradation of high-molecular-weight molecules, furthering a greater amount of metabolizing cells and enzymes, and subsequently raising the amount of enzyme activity potential. Our data confirm this hypothesis and it appears that similar values could be expected in other fjords.

A lower FDA activity was found on the surface of the sediment than a few $\mathrm{cm}$ deeper (Fig. 2). Such vertical profiles are reported from stations where infauna organisms (e.g. enteropneusts, echiurans, anthozoans) transported material into deeper layers (Köster et al., 1991). In other cases, sub-surface peaks of FDA activity have been found close to the interface of the redox-discontinue-layer. There may have been both events in the Sognefjord. Infaunal organisms and signs of bioturbation have been found, but unfortunately neither a quantification of higher organisms nor any redox measurements have been performed. Further studies should take into account such determinations, enabling a better understanding of the vertical FDA-activity profile in the Sognefjord.

Additional experiments on microbial respiratoric activity were processed with ${ }^{14} \mathrm{C}$ labeled cyanobacteria as food for the benthic organisms. The liberation of labeled $\mathrm{CO}_{2}$, formed during biological oxidation/degradation, was measured. The amount of the supplemented carbon was low $\left(1.89 \mathrm{nmol} \mathrm{C} \mathrm{cm}{ }^{-3}\right)$, and the natural concentration of substrate had been altered to a smaller extent than in the FDA-assay, described before. 
DEPTH SUB-BOTTOM $(\mathrm{cm})$

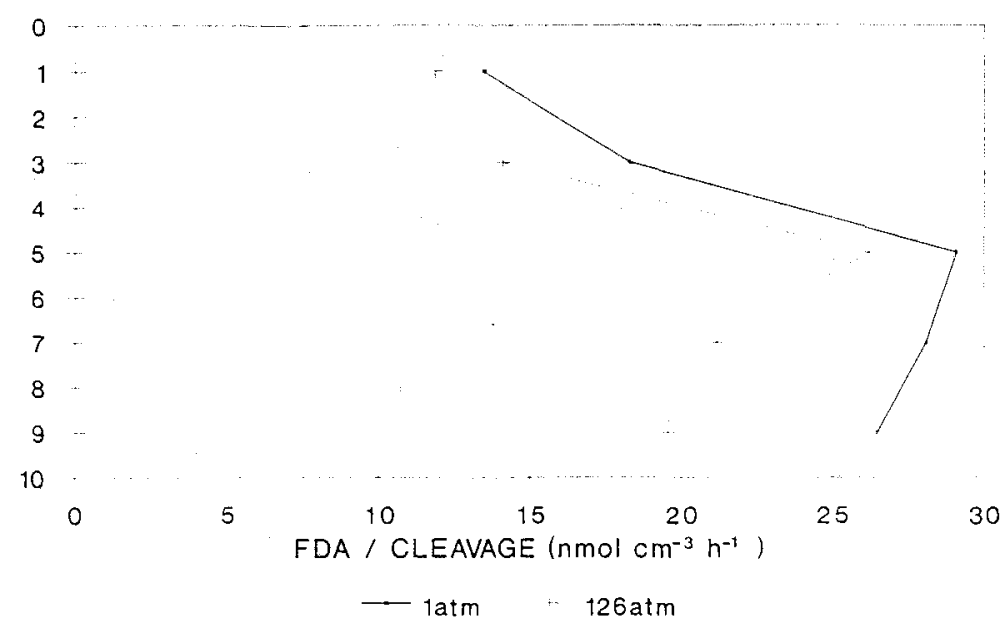

Fig. 2. Vertical profile of the potential hydrolytic enzymatic activity (measured as nmol FDA cleavage per $\mathrm{cm}^{-3} \mathrm{~h}^{-1}$ ). Incubations were performed over $4 \mathrm{~h}, 7^{\circ} \mathrm{C}$, and at 1 or $126 \mathrm{~atm}$ pressure, respectively

The production of $\mathrm{CO}_{2}$ increased in the first 2 days, declining, or remaining more or less constant later, as shown in Figure 3. Such a two-step kinetic of degradation versus time was reported also by Lochte (1992) and was attributed to the primary utilization of easily degradable material and the successive shift in the consumption of less labile

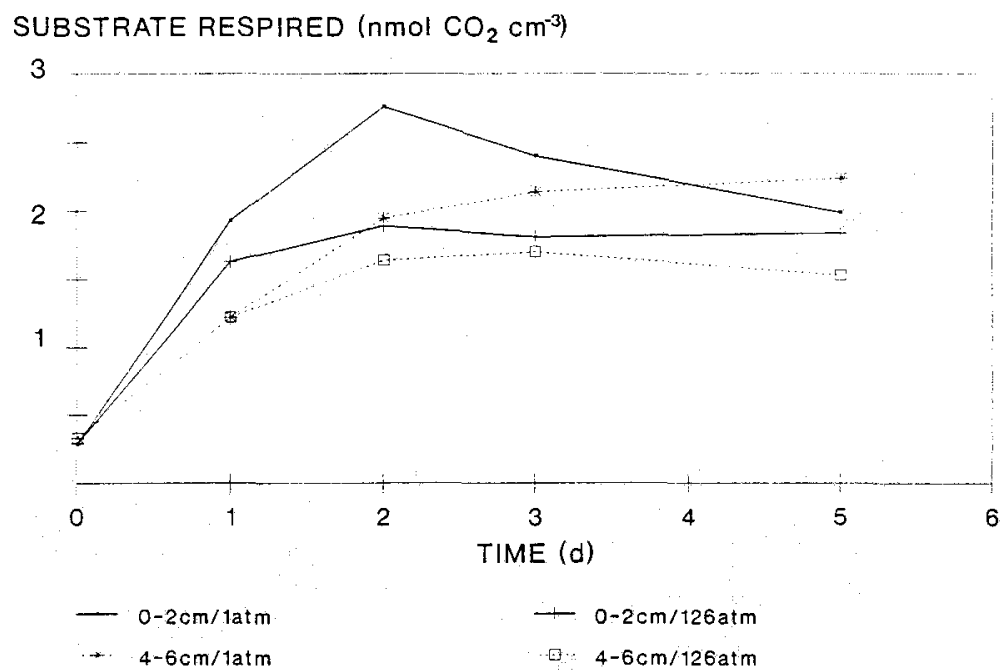

Fig. 3. Respiratoric degradation of ${ }^{14} \mathrm{C}$ labeled cyanobacteria (measured as $\mathrm{nmol} \mathrm{CO}_{2} \mathrm{~cm}^{-3}$ ) by the henthic population of the Sognefind 
organic matter (Turley \& Lochte, 1990). Only the first part of the time curves was used for the calculation of degradation rates.

Faster mineralization rates were found in the top 0-2 cm surface layer compared to the deeper 4-6 cm layer (Table 1). This was expected, because the sediment surface is the accumulation zone of organic material, especially settling detritus. The same was reported by Lochte (1992), who tested the 0-1 and 6-7 cm layers of deep-sea sediment of two different sites in the NE Atlantic. The absolute degradation rates found in the Sognefjord are not very different from those in the NE Atlantic, especially when the data of incubation series performed at $1 \mathrm{~atm}$ pressure are compared (Table 1). It has to be mentioned that all details of these experiments including the algae concentration were identical. A possible explanation of the similarity of these values may be a dilution effect: the deep sea is an extremely oligotrophic environment, while the Sognefjord is a (relatively) rich one, because the input of terrestrial material reaching the bottom of the fjord is much greater. Therefore, the background of unlabeled material in the fjord was possibly greater than in the deep sea. Most probably, the true substrate dilutions in both environments are not identical, and therefore a comparison of absolute data is maybe misleading.

Both the FDA-assay and the respiration-assay were processed at $1 \mathrm{~atm}$ and at 126 atm pressure, respectively. In both cases, higher activity was found at $1 \mathrm{~atm}$ and not in the series simulating in situ conditions. This indicates that the benthic populations in the fjord were not adapted to pressure conditions. In contrast to this, barophilic response was found in the pressure experiments by Lochte (1992), shown in Table 1 . This may be due to the greater depth of the environment tested there. All the barophiles known today were found in biotopes of $4000 \mathrm{~m}$ depth or deeper (Deming et al., 1981; Deming \& Colwell, 1982, 1985; Jannasch \& Wirsen, 1982; Rowe \& Deming, 1985; Turley et al., 1988; Yayanos et al., 1979, 1981). Meyer-Reil \& Köster (1992) also missed barophile response in their FDA-measurements in the Norwegian-Greenland Sea (up to $2000 \mathrm{~m}$ deep). It is possible that in the Sognefjord no barophilic organisms occur, because the fjord is too shallow to

Table 1. Respiratoric degradation of cyanobacteria in sediment expressed as $\% \mathrm{CO}_{2}$ that theoretically could be formed through the total oxidation of the substrate added. During the experiments 1 atm or the in situ pressure conditions were maintained (Sognefjord: $126 \mathrm{~atm}$, NE Atlantic: 450/500 atm). Data from NE Atlantic were taken from Lochte (1992)

\begin{tabular}{|lcc|}
\hline $\begin{array}{l}\text { Sediment } \\
\text { surface pressure }\end{array}$ & $1 \mathrm{~atm}$ Pressure conditions \\
& & in situ \\
\hline Sognefjord, $61^{\circ} \mathrm{N} / 06^{\circ} \mathrm{E}, 1260 \mathrm{~m}$ deep & & \\
$0-2 \mathrm{~cm}$ & 1.24 & 0.80 \\
$4-6 \mathrm{~cm}$ & 0.81 & 0.67 \\
$\mathrm{NE} \mathrm{Atlantic,} 47^{\circ} \mathrm{N} / 19^{\circ} \mathrm{W}, 4500 \mathrm{~m}$ deep & & \\
$0-1 \mathrm{~cm}$ & 1.4 & 2.3 \\
$6-7 \mathrm{~cm}$ & 1.2 & 1.4 \\
$\mathrm{NE} \mathrm{Atlantic,} 34^{\circ} \mathrm{N} / 19^{\circ} \mathrm{W}, 5000 \mathrm{~m}$ deep & 1.5 & 1.4 \\
$0-1 \mathrm{~cm}$ & 0.6 & 0.3 \\
$6-7 \mathrm{~cm}$ & & \\
\hline
\end{tabular}


favour such specialists. Although hydrostatic pressure may damage higher organisms, its influence on the physiology of microorganisms is smaller. Increase of temperature has a much greater effect on microbes than pressure shifts (Chastain \& Yayanos, 1991; Jaeneke, 1991). It is possible that barophiles occur only in environments that are deep enough for a physiological adaptation to elevated pressure to be an advantage for survival in the environment. Such environmental niches may be given in depths greater than $2000 \mathrm{~m}$. On the other hand, the quality and quantity of labelled substrates in assays are known to have a major influence on the degree of barophily measured (Jannasch \& Wirsen, 1973, 1982, 1984). The traditional single substrate method to determine uptake or incorporation kinetics uses radioactively labelled substrates such as glucose, acetate, or glutamate. The method used here with labelled Anacystis sp., added in a relatively low amount, may alter in situ conditions for the microbes to a less extent than traditional assays, because cyanobacteria are a more representative food source in nature. However, we do not know if the cyanobacteria are a representative food and appropriate for physiological studies in the Sognefjord.

Our data present the first report on microbial activity in the sediment of the Sognefjord. The Sognefjord is a rather extreme and distinct environment, therefore our data can not be compared directly with those of other marine benthic environments. Comparisons made here can only help to fit the presented data into the general frame of information. Further investigations are needed with similar experiments at other stations of the fjord, or at the same station, but in other seasons. Moreover, such experiments should look in more detail at the kinds of substrates available in the Sognefjord and on their natural concentration.

Acknowledgements. We thank the crew of RV "Alkor" and scientists of the BIOCFLUX project, especially K. Lochte for her support in the laboratory and discussion of results, R. Koppelmann for performing CTD-measurements, $O$. Pfannkuche for the scientific guiding the cruise, and $H$. G. Hoppe for comments on the manuscript. This work was supported by Grant 03F0565A from the Bundesministerium für Forschung und Technik. This is BIOTRANS publication No. 34 .

\section{LITERATURE CITED}

Barnett, P. R. O., Watson, J. \& Connely, D., 1984. A multiple corer for taking virtually undisturbed samples from shelf, bathyal and abyssal sediments. - Oceanol. Acta 7, 399-408.

Billen, G., 1982. Modelling the processes of organic matter degradation and nutrient recycling in sedimentary systems. In: Sediment microbiology. Ed. by D. B. Nedwell \& C. M. Brown. Acad. Press, London, 15-52.

Boetius, A., 1995. Microbial enzyme activity in deep-sea sediments. - Helgoländer Meeresunters. $49,177-187$.

Chaistain, R. A. \& Yayanos, A. A., 1991. Ultrastructural changes in an obligately barophilic marine bacterium after decompression. - Appl. environ. Microbiol. 57, 1489-1497.

Christiansen, B., 1993. A television and photographic survey of megafaunal abundance in the central Sognefjord, western Norway. - Sarsia 78, 1-8.

Chrost, J., 1990. Microbial ectoenzymes in aquatic environments. In: Aquatic microbial ecology biochemical and molecular approaches. Ed. by J. Overbeck \& R. J. Chrost. Springer, New York, 47-78.

Deming, J. W. \& Colwell, R. R., 1982. Barophilic bacteria associated with digestive tracts of abyssal holothurians. - Appl. environ. Microbiol. 44, 1222-1230.

Deming, J. W. \& Colwell, R. R., 1985. Observations of barophilic microbial activity in samples of 
sediment and intercepted particulates from the Demerara Abyssal Plain. - Appl. environ. Microbiol. 50, 1002-1006.

Deming, J. W., Tabor, P. S. \& Colwell, R. R., 1981. Barophilic growth of bacteria from intestinal tracts of deep-sea invertebrates. - Microb. Ecol. 7, 85-94.

Freeland, H. J., Farmer, D. M. \& Levings, C. D., 1980. Fjord oceanography. Plenum Press, New York, $715 \mathrm{pp}$.

Hoppe, H. G., 1983. Significance of exoenzymatic activities in the ecology of brackish water: measurements by means of methylumbelliferyl-substrates. - Mar. Ecol. Prog. Ser. 11, 299-308.

Jaeneke, R., 1991. Protein stability and molecular adaptation to extreme conditions. - Eur. J. Biochem. 202, 715-728.

Jannasch, H. \& Wirsen, C. O., 1973. Deep-sea microorganisms: in situ response to nutrient enrichment. - Science, N.Y. 180, 641-643.

Jannasch, H. \& Wirsen, C. O., 1982. Microbial activities in undecompressed and decompressed deep-seawater samples. - Appl. environ. Microbiol. 43, 1116-1124.

Jannasch, H. \& Wirsen, C. O., 1984. Variability of pressure adaptation in deep sea bacteria. - Arch. Microbiol. 139, 281-288.

Köster, M., 1992. Mikrobieller Abbau von organischem Material an Grenzzonen. Diss., Univ. Kiel, $148 \mathrm{pp}$.

Köster, M., Jensen, P. \& Meyer-Reil, L. A., 1991. Hydrolytic activity associated with organisms and biogenic structures in deep-sea sediments. In: Microbial enzymes in aquatic environments. Ed. by R. Chrost. Springer, Berlin, 298-310.

Lochte, K., 1992. Bacterial standing stock and consumption of organic carbon in the benthic boundary layer of the abyssal North Atlantic. In: Deep-sea food chains and the global carbon cycle. Ed. by T. Rowe \& V. Pariente. Kluwer, Dordrecht, 1-10.

Meyer-Reil, L. A., 1990. Microorganisms in marine sediments: considerations concerning activity measurements. - Arch. Hydrobiol. Beih. Ergebn. Limnol. 34, 1-6.

Meyer-Reil, L. A. \& Köster, M., 1992. Microbial life in pelagic sediments: the impact of environmental parameters on enzymatic degradation of organic material. - Mar. Ecol. Prog. Ser. 81, $65-72$.

Rowe, G. T. \& Deming, J. W., 1985. The role of bacteria in the turnover of organic carbon in deep-sea sediments. - J. mar. Res. 43, 925-950.

Turley, C. M. \& Lochte, K., 1990. Microbial response to the input of fresh detritus to the deep-sea bed. - Paleogeogr. Paleoclimatol. Paleoecol. 89, 3-23.

Turley, C. M., Lochte, K. \& Paterson, D. J., 1988. A barophilic flagellate isolated from $4500 \mathrm{~m}$ in the mid-North Atlantic. - Deep Sea Res. 35, 1079-1092.

Yayanos, A. A., 1969. A technique for studying biological reaction rates at high pressure. - Rev. scient. Instrum. 40,961-963.

Yayanos, A. A., Dietz, A. S. \& van Boxtel, R., 1979. Isolation of a deep-sea barophilic bacterium and some of its growth characteristics. - Science, N.Y. 205, 808-809.

Yayanos, A. A., Dietz, A. S. \& van Boxtel, R., 1981. Obligately barophilic bacterium from the Mariana Trench. - Proc. natn. Acad. Sci. U.S.A. 78, 5212-5215. 